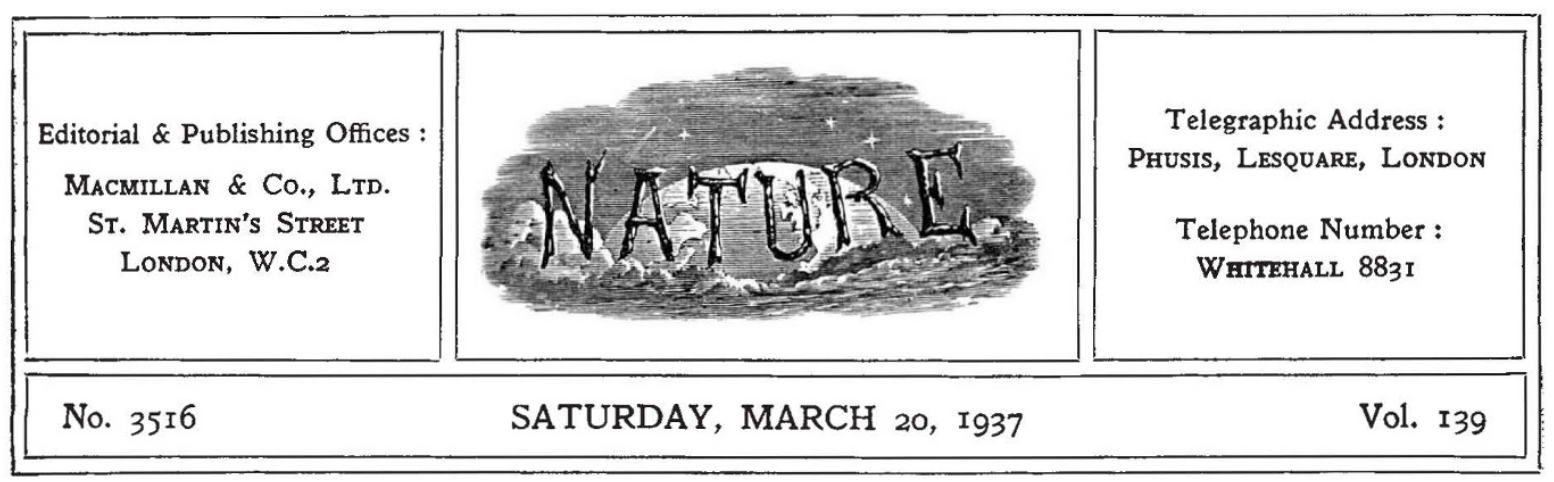

\title{
Promotion of International Peace
}

$\mathrm{T}$ HE attention which has been given in Great Britain during the past few months to considerations of defence and the Government's programme of rearmament, despite all the scepticism expressed as to any effective defence against attack from the air, has rather over-shadowed the other side of defence against war-the removal of its causes. To this positive aspect of the question the International Peace Campaign has the great merit of directing attention, and the appeal for support of the British National Committee of the Campaign, which has recently been issued over the signature of Viscount Cecil, has claims on the interest of every scientific worker.

The need for a more balanced handling of the problem of peace and national defence is unquestioned by well-qualified observers. The International Peace Campaign, as Viscount Cecil points out, has come into existence for the sole purpose of arresting the drift towards war, and aims at strengthening and co-ordinating organizations which already exist and are interested in peace, and although its organization takes no part in party politics, it is all the more important that it should secure support from all sections of political opinion if its policy and development are to be free from bias, however unconscious or unintentional.

The four objectives of the campaign naturally include the reduction and limitation of armaments by international agreement and the suppression of profit from the manufacture and trade in arms. This objective is not, however, over-stressed, and its practical impossibility at the time need not deter the most convinced supporter of the Government programme from supporting the Campaign, while at the same time it serves as a reminder of the necessity of such action when international tension is lessened and a positive defence policy bears fruit.

The first objective of the Campaign, however, the recognition of the sanctity of treaty obligations, should command universal assent. However inapplicable the provisions of the Versailles treaty may be under the conditions of to-day, and however overdue their supercession, the method of unilateral repudiation adopted by Germany has dealt heavy blows at the assumption of international good faith and the respect for treaties upon which all international order and co-operation are finally based. It is not merely that Germany's other treaty obligations are viewed by other countries with the same cynicism and distrust as have been Italy's since her Abyssinian expedition -a cynicism which no announcements of Mediterranean agreements or understandings can dispelbut also confidence has been undermined, and mutual distrust, itself the chief enemy of peace, has been greatly multiplied.

It is on this main point that Dr. L. P. Jacks insisted in a recent thoughtful criticism of the League Covenant contributed to the Hibbert Journal under the title "Alexander Hamilton and the Reform of the League". Covenants between sovereign States can depend only on the good faith of the contracting parties, and if that is insecure nothing can be made safe. Coercive measures intended to circumvent bad faith are exposed to the bad faith they would circumvent, and indeed are more vulnerable to it, since they tend to emphasize any bad faith which exists, inflame it and afford fresh opportunities of mischief. Accordingly, Dr. Jacks urges that the elimination from the Covenant of the last traces of the coercive element and the fatal assumption upon which it 
rests would have an immense and salutary psychological effect.

This argument that the better atmosphere thus created would permit the League of Nations to achieve far more effectively its proper function of protecting human welfare by international cooperation on positive lines finds strong support in a careful study of public opinion as a safeguard to peace delivered by Prof. E. H. Carr as the inaugural lecture of the Wilson chair of international politics at University College, Aberystwyth, on October 14. Reviewing the various divergent sections of opinion, from the pacifist and the isolationist to the collectivist, which to-day are found supporting the cause of peace, Prof. Carr emphasizes the necessity of regarding international politics not as a pure but as an applied science, in accordance with Aristotle's assertion that "the end of the study of politics is not knowledge but practice". Accordingly, he does not regard a system of collective security involving automatic military obligations as likely to gain sufficient support in Great Britain to be practical. $\mathrm{He}$ believes, on the contrary, that in this country public opinion is not prepared to support war as an instrument of any kind of policy, whether in defence of collective security or not.

Prof. Carr maintains that support of the Covenant in Great Britain is, in fact, subject to the over-riding consideration that it involves no risk of bringing the country into war, and that public opinion will not be prepared for many years to apply the Sanctions article against a Great Power. Although he does not discuss the amendment of the Covenant, as a matter of practical politics, support of Dr. Jacks' suggestion might be read as a corollary of his remarks.

There will accordingly be perhaps less unqualified support for the third objective of the International Peace Council-the strengthening of the League of Nations for the prevention and stopping of war by the organization of collective security and mutual assistance. Though Prof. Carr's belief in the possibility of isolating war will not be shared by many, and though he asserts his disbelief that the time is ripe for the establishment of anything like an international police force, there is still plenty of ground in common with the supporter of collective security. Public opinion undoubtedly presents a far more determined obstacle to warmongering in any form than it did a generation ago. The area of the world's surface over which war has become unthinkable has been immensely extended, and with wise handling might even yet be much greater, despite the great tragedies of missed opportunities which have marked the last two decades. The increased power of Governments to-day of influencing public opinion, whether by broadcasting or through the Press, should warn us against overrating the restraining effect of public opinion in any time of crisis except in so far as it is really informed and independent. Moręover, the whole trend of events in Spain and in Abyssinia strengthens the case for organizing effectively collective force behind law if civilization is to be preserved.

The most urgent problem if peace is to be preserved and democracy survive is in fact that of peaceful change, which forms the fourth objective of the Campaign and upon which Prof. Carr lays the greatest stress. The establishment within the framework of the League of effective machinery for remedying international conditions which might lead to war is the most urgent task of our generation, and offers an immense field for impartial scientific investigation. There can be no rule of law unless there is working machinery for making and re-making law, and no sanctity of treaties without effective means for altering or re-making treaties which are no longer applicable to the prevailing conditions.

Nothing in fact is so imperative at the present time as the need for demonstrating that such questions as raw materials, population, colonial territories and the like can be dealt with justly and impartially by a process of peaceful change and not merely at the demand of force majeure. The greatest function of public opinion, whether expressed through the International Peace Cam. paign, or in any other way, is to insist on the Government exploring the possibilities in this way to the utmost so as to remove and not engender further friction. Nor should it be forgotten that peace is dynamic and not static, and, just as much as war, involves risks and ventures. Only as the nations and the Governments are prepared to run those risks and to make those ventures can we hope to develop a civilization and a social and international order in which in days of peace the human mind and spirit can find expression no less nobler than they have done in the past in days of national extremity or calamity in war. A creative peace is in fact a first essential if science, no less than art and religion, is to retain its full freedom of expression and bring yet richer treasures to the service and inspiration of mankind. 